\title{
Challenges IT Instructors Face in the Self-Education Process
}

\section{Ljiljana Ružić-Dimitrijević The Advanced Technical School, Novi Sad, Serbia}

ljaga@eunet.yu

\author{
Maja Dimitrijević \\ SAT Consulting, Vancouver, \\ Canada
}

maja@lale.ca

\section{Executive Summary}

Every few years, there is a breakthrough in information technology, introducing a new concept that becomes widely used. This paper deals with the challenges IT (information technology) instructors face due to these rapid developments in the IT industry. More specifically, we are interested in the challenges instructors of the introductory IT courses face in staying current with technology and its use in business. In order to accurately evaluate the instructors' challenges and identify how instructors overcome them, we have conducted a survey among IT instructors and presented the results.

The survey includes IT instructors who teach at various colleges and universities in several countries. We are specifically interested in the experience of the IT instructors who teach introductory computer science courses, as they are often heavily affected by the information technology changes.

The data gathered in our survey addresses the following hypotheses:

[H1] The technology studied by the IT instructors when they were in school is not the one they must now teach.

[H2] The course syllabus of the introductory IT courses changes every two or three years due to the technology changes.

[H3] The instructors primarily self-teach new technologies by using textbooks.

$[\mathrm{H} 4]$ The lack of time is one of the major challenges IT instructors face in their self-education.

According to the survey results, most IT instructors now teach different technologies than those they had studied, which supports the first hypothesis. In the analysis of our survey, we compare the year the instructors graduated, the technology they studied, and the technology they now teach. We find that the earlier the instructors graduated, the smaller is the chance they studied the technologies similar to the ones they teach. We found that none of the surveyed instructors who

Material published as part of this publication, either on-line or in print, is copyrighted by the Informing Science Institute. Permission to make digital or paper copy of part or all of these works for personal or classroom use is granted without fee provided that the copies are not made or distributed for profit or commercial advantage AND that copies 1) bear this notice in full and 2) give the full citation on the first page. It is permissible to abstract these works so long as credit is given. To copy in all other cases or to republish or to post on a server or to redistribute to lists requires specific permission and payment of a fee. Contact Publisher@InformingScience.org to request redistribution permission. graduated before 1979 teach a technology they studied.

The analysis of the survey also supports the second hypothesis. The results show that $70 \%$ of the IT instructors have to change the course syllabus every $2-3$ years due to the technology changes.

We also found that the majority of the instructors primarily use textbooks and online tutorials to self teach new tech- 
nologies, which supports the third hypothesis. By comparison, they take courses given by others and work on real life projects far less often. In contrast, most instructors agree that taking courses and working on projects would greatly help them in their self-education. Most instructors (16 out of 20) assert that the lack of time stops them from doing so, which according to the survey is found to be one of the major challenges they face in the process of self-education, supporting the fourth hypothesis.

Considering the results of our research, as well as our own experience, we have identified a list of activities that make the process of self-education more efficient and/or effective for IT instructors. These activities include taking on-line tutorials, creating software programs using the environment/language/tools covered in the courses, working on real life projects, taking organized courses, attending IT/CS conferences, seminars, and workshops, collecting experience from industry people, and using the help of advanced students.

However, in order to create the time for IT instructors to apply the self-learning methods and stay on top of the new technologies, we conclude that it may be necessary that the university policy include the time for self-learning as a significant part of IT instructors' everyday duties, i.e., as a part of their "job description."

\section{Introduction}

Nowadays information technology is involved in virtually all aspects of our life. It affects the ways of business, communication, and education. IT offers many improvements to teaching and learning, including a wide market of teaching software, distance learning, etc. (McGill, 2003). Everyone must be prepared to learn new IT skills continuously, and this includes IT instructors.

While reviewing the related literature, we have found a gap in the research specifically related to the need for continuous self-education of IT instructors.

According to Turner (2005), there are about 20 basic technology skills that all educators should now have. They include word processing, spreadsheet, database, electronic presentation, web navigation, email management, and many other skills. For example, e-learning is becoming a popular means of education and teachers need to be able to use the software to manage it (e.g., WebCT, Blackboard, Moodle).

There is considerable research focused on applying information technology in teaching (Cromley, 2000) and training educators in using the new technologies (Cox, 2007; Cuban, 2003; Resta, 2002). For example, adopting information technologies allows publishing course material online, using online tutorials, etc. Therefore, all teachers should have basic IT literacy (Crawford, 2000). Cox (2007) emphasizes that teachers do not finish their education with graduation, but have to improve their skills and learn new technologies continuously. However, there are not many resources on continuous training of the IT tutors themselves, which is the focus of our research.

There are rich literature resources in the areas of teaching styles and pedagogy applied to teaching IT (Crawford, 2000). The material on training IT tutors often focuses on issues such as theory and practice, program design, and pedagogy. For example, Luger (2006) only mentions that ICT teachers have an especially high need for self-directed personal-development. Similarly, it is emphasized (Cohen, 2002; Dadashzadeh, Saber, \& Saber, 2002) that IT educators have to change the ways in which students are taught as well as the syllabuses' content to match technology development.

The instructional content of IT courses should focus on the underlying theory, concepts, and principles, rather than on the specific details of the current technology. However, in order for an IT course to be enticing for the students and to effectively prepare them for work right after gradua- 
tion, the theory and principles taught in the course should be anchored to the current technology and demonstrated using it (Helps \& Renshaw, 2004).

Considering the speed of the information technology development that is emphasized throughout the literature and the need for IT instructors to constantly remain up-to-date with it, leads us to the following hypotheses:

[H1] The technology studied by the IT instructors when they were in school is not the one they must now teach.

[H2] The course syllabus of the introductory IT courses changes every two or three years due to the technology changes.

[H3] The instructors primarily self-teach new technologies by using textbooks.

[H4] The lack of time is one of the major challenges IT instructors face in their self-education.

In order to test these hypotheses, we have conducted a survey among IT instructors who teach at various colleges and universities in several countries. Specifically, our focus is on the experience of the IT instructors who teach introductory computer science courses, as they are often heavily affected by information technology changes.

The remainder of the paper is organized as follows: We discuss the issues related to teaching introductory IT courses in the next section, and the issues related to the self education of IT educators in the following section. The survey and the analysis of its results are presented in the Research Methodology, Results Analysis, and Discussion sections. Finally, the section Conclusion outlines the conclusions we have found.

\section{Designing an Introductory IT Course}

One of the challenges IT instructors face due to the fast speed of the IT development is having to frequently update course syllabuses, and this is especially true for introductory IT courses (Dadashzadeh, Saber, \& Saber, 2002). In this section, we discuss the content of an introductory IT course and some of the issues that affect it.

Students of an introductory computer science course have various levels of prior knowledge acquired in their previous education. When designing an introductory course the content must not be too difficult for the beginners to follow or too easy for the students with more advanced prior knowledge.

The basic goal of an introductory IT course is to produce technically literate students who can use a computer at workplace or at school. Information technology is heavily applied in education; teachers use it to support their lectures, and it is usually required that students have basic IT skills and use them when working on their assignments (Johnson, Bartholomew, \& Miller, 2006). The content of an introductory IT course has to expand to satisfy the extended definition of technology literacy. It should involve both computer and information literacy, which means using the computer as a collection of applications, the way of communication, and the source of information (Hoffman \& Blake, 2003). However, a model curriculum which formulates basic content to be included in the introductory IT courses is often hard to achieve due to the time limitations (Aasheim, Lee, \& Reichgelt, 2006).

Due to the changes in the IT industry, the content of an IT course should be as robust as possible. An example of a successful attempt to design such a robust IT course in operating systems is presented in Helps and Renshaw (2004). This to some extent alleviates the problem of the course becoming outdated due to the technology advancements while it does not completely overcome it. It is hardly possible to design an IT course that will be completely independent on the current technology, while still attractive for students and useful for their future careers. 
Another possible reason for changes of the syllabus of an introductory IT course is its dependency on subsequent courses. Changes made to subsequent courses often require changes in the syllabus of the introductory course.

In order to quantify the frequency of changing an introductory IT course syllabus due to the technology advancement and test our hypothesis $\mathrm{H} 2$, we have included related questions in the survey conducted among IT instructors, and these results are presented in the Results Analysis section.

\section{An Example of a Dynamic IT Curriculum}

In the Advanced Technical School in Novi Sad, where one of the authors teaches, the first syllabus of the course Introduction to Computers included DOS and BASIC. In 4 years, it changed and included Windows 3.1 and DBASE. Over the next few years it was updated to the current version of the Windows $(95,98, \mathrm{XP})$ and the OFFICE.

Further, when the School opened the Graphics Department in 1996, our students needed knowledge of text and image processing. We included new software technologies in the curriculum: Photoshop, CorelDraw, Quark Express, and In Design. Then, with the development of the Internet, we had to teach the students some basic Internet development languages and tools, such as HTML, CSS, Dreamweaver, and Flash.

The instructors of the second year courses in the Graphics Department expect their students to master all software needed for their subjects during the first year. Even in the second semester of the first year, they must know how to use Photoshop, because some courses, such as Graphic Design, require image processing.

Currently, there are two courses from the IT area at the Graphics Department: Computers, in the first semester, and Computer Graphics in the second. The Computers course involves computer development, hardware components, operating systems, text processors, presentation software, and image editing software (Windows, Word, PowerPoint, and Photoshop). The Computer Graphics course deals with the principles and tools of interactive computer graphics (Corel Draw and In Design). In the second year, there are courses as Typography, Reproduction Technology, and others, requiring the knowledge of the above mentioned software. This is the current situation, and it will certainly change over the next few years.

Furthermore, in 2004 we started a new study group - Web Design. In 2005 we made some major changes in the syllabus of several courses (Krunic, Ruzic-Dimitrijevic, Petrovic, \& Farkas, 2005). Since then, the syllabus has been futher updated. For example, the syllabus of Computer Graphics includes InDesign instead of FreeHand, Development of the Internet includes HTML and DreamWeaver, and Internet Languages and Tools includes ASP technology. Further, we added a new course called Database Structures, which teaches the students database architecture and SQL, and is a prerequisite for taking Applied Databases, allowing the students to gain more knowledge about database structures, as well as database web application development (Applied Databases).

The curriculum and syllabus of most of our introductory IT courses has been highly dynamic and changed significantly every 1-3 years since 1996 . While our experience with the introductory IT courses at our university is unlikely to be representative globally in terms of content, we do believe that the pace and range of changes is typical. Our research was designed to test this contention.

\section{IT Educators and Self-Education}

Self-directed learning, or self-education, dates back to ancient Greece. Most Greek philosophers and mathematicians were self-directed learners. Also, in many other historical periods people learned on their own due to the lack of educational institutions (Hiemstra, 1994). 
Nowadays with the various means of communication, students do not even need to be physically present in an educational institution. Technology development enables distance learning at many colleges and universities. In addition, there are numerous resources for facilitating self-directed learning: self-help books, support groups, open-university programs, computer-assisted learning (on-line tutorials), etc.

At present, many work places require frequent learning of new skills. In order to professionally advance, one needs to be a self-directed learner. This is also true for teachers whose education is a life-long process (Cox, 2007; Resta, 2002). A large part of it includes learning the latest information technologies applied in education (Crawford, 2000).

Updating skills and learning current technologies continuously is expected from all educators (Turner, 2005). This is even more so for IT instructors, who have to be the first to adopt the new technology and master new skills (Luger, 2006). The knowledge of IT teachers has more complex requirements than the teaching of many other subjects due to the rapid development of information technology (Webb, 2002).

We base our hypotheses $\mathrm{H} 3$ and $\mathrm{H} 4$ on those facts and test them through the survey whose results are described in the following sections.

\section{Research Methodology}

We have conducted a survey (the complete list of questions can be found in Appendix A) among 20 IT instructors from 10 colleges and universities from Serbia, Canada, the USA, Nigeria, and Great Britain (Appendix B). The questionnaire was sent by email to 42 IT instructors at 18 universities and the response rate was $48 \%$. We received 20 completed questionnaires from 10 universities.

The survey includes questions about the courses recently taught, the technologies used at each course, the frequency of changing the course syllabuses and the reasons for that, and similar items. In order to answer the question about the importance of practice and real life work for IT instructors, we also asked the instructors about their experiences with having someone from the industry teach a part of their course, as well as their own experiences with real life project work. In order to obtain recommendations from teachers with different experiences regarding IT studies that could help their colleges, we included questions about useful techniques to improve the process of self-education.

The survey contains several question types. Most of the questions are open-ended (1-6, 10-12). Questions 4, 5, 6, and 11 are numeric open-ended, while 1, 2, 3, 10 and 12 are text open-ended. Questions 7, 8 and 9 are partly close-ended. Question 7 is dichotomous. Questions 8 and 9 are multiple choice matrix type and scaled by a semantic 3-point differential scale. In addition, they are partly open-ended as there is an option to add another answer besides those offered.

\section{Results Analysis}

\section{Technology studied vs. technology teaching (Hypothesis H1)}

In regards to testing hypothesis $\mathrm{H} 1$, we analyze the survey results related to the questions about the year the instructors graduated, the technology studied, and the technology taught.

Table 1 shows the technologies the instructors studied during their own studies and the technologies they have taught over the last 10 years. 
Table 1: The year graduated and the software technologies studied

\begin{tabular}{|c|c|c|c|c|c|c|c|c|c|c|c|c|c|}
\hline \multirow{2}{*}{$\begin{array}{l}\text { Gradu- } \\
\text { ated }\end{array}$} & \multirow{2}{*}{$\begin{array}{l}\text { Number of } \\
\text { instructors }\end{array}$} & \multicolumn{2}{|c|}{ FORTRAN } & \multicolumn{2}{|c|}{ PASCAL } & \multicolumn{2}{|c|}{ DOS } & \multicolumn{2}{|c|}{$\begin{array}{l}\text { WINDOWS/ } \\
\text { UNIX/MAC }\end{array}$} & \multicolumn{2}{|c|}{$\mathrm{C}, \mathrm{C}++$} & \multicolumn{2}{|c|}{ JAVA } \\
\hline & & $\mathbf{S}$ & $\mathbf{T}$ & $\mathbf{S}$ & $\mathbf{T}$ & $\mathbf{S}$ & $\mathbf{T}$ & $\mathbf{S}$ & $\mathbf{T}$ & $\mathbf{S}$ & $\mathbf{T}$ & $\mathbf{S}$ & $\mathbf{T}$ \\
\hline $\begin{array}{l}1969- \\
1979\end{array}$ & 4 & 3 & - & - & 1 & - & - & - & 3 & - & - & - & - \\
\hline $\begin{array}{l}1980- \\
1989\end{array}$ & 7 & 3 & - & 4 & - & 4 & - & - & 5 & 3 & - & - & 4 \\
\hline $\begin{array}{l}1990- \\
1998\end{array}$ & 9 & 4 & - & 9 & 2 & 1 & - & 6 & 6 & 5 & 3 & 4 & 6 \\
\hline Total & 20 & 10 & - & 12 & 3 & 4 & - & 6 & 14 & 8 & 3 & 4 & 7 \\
\hline
\end{tabular}

The instructors are divided in 3 groups according to the year they graduated. Four instructors graduated before 1979, seven between 1980 and 1989, and nine after 1990.

The table shows how many instructors in each group had studied each technology (columns ' $\mathrm{S}$ ') and how many instructors have taught it over the last 10 years (columns ' $\mathrm{T}$ ').

Most instructors have taught different technologies than those they had studied. About half of all the instructors had studied FORTRAN and PASCAL and no operating system, while the majority of the instructors now teach an operating system (usually Windows) and/or a contemporary programming language (most often Java).

Instructors who graduated after 1990 more often teach the technologies they had studied, but even among them it is not always so. For example, as we can see in Table 1, 4 of those instructors studied Fortran, but none teaches it, while another 4 of them studied Java, but 6 of them teach it.

None of the instructors who graduated before 1979 teaches a technology he or she had studied.

Two out of the 20 instructors did not even study the IT area in their undergraduate studies. Nonetheless, they currently teach Windows and Software Project Management.

Obviously, the results support the hypothesis H1, that is the technology studied is different then the technology taught for the majority of IT instructors.

\section{Changes of the course syllabus}

In regards to testing the hypothesis $\mathrm{H} 2$, we analyzed the questions related to the frequency of changes to the course syllabus.

Table 2 shows how frequently the instructors needed to change the course syllabus due to the advancements of software technology and in order to meet the requirements of other courses. For each question, the instructors chose one of the offered answers that are listed in the first column of the table. The number of instructors who selected each answer are given in the table cells. 
Table 2: Course syllabus changes due to the technology advancements and the requirements of other courses

\begin{tabular}{|c|c|c|}
\hline & $\begin{array}{c}\text { Technology } \\
\text { Advancements }\end{array}$ & $\begin{array}{c}\text { Requirements Of } \\
\text { Other Courses }\end{array}$ \\
\hline Every Year (3) & $3(15 \%)$ & $2(10 \%)$ \\
\hline Every 2-3 Years ( 2) & $14(70 \%)$ & $6(30 \%)$ \\
\hline Rarely ( 1) & $3(15 \%)$ & $8(40 \%)$ \\
\hline Never ( 0 ) & - & $4(20 \%)$ \\
\hline
\end{tabular}

The table shows that $70 \%$ of the instructors (14 out of 20 ) have to change the course syllabus due to the changes in software technology every $2-3$ years, while another $15 \%$ ( 3 out of 20 ) have to change it every year. None of the instructors indicated he or she never had to change the course syllabus due to the technology advancements.

The majority of instructors claim that they need to change the course syllabus every 2-3 years due to technology advancements, which supports hypothesis $\mathrm{H} 2$.

The situation is somewhat different regarding changes to the syllabus due to the requirements of other courses. The table shows that those changes are less frequent. This may be a result of how questions were interpreted, or the requirements of other courses may not be as heavily influenced by technology advancements. This is an area for future research.

Table 3 compares the frequency of updating the course syllabuses and textbooks due to the technology advancements.

Table 3: Course syllabus and textbook changes due to technology advancements

\begin{tabular}{|c|c|c|} 
& $\begin{array}{c}\text { Course } \\
\text { Syllabus }\end{array}$ & Textbooks \\
\hline Every Year (3) & $3(15 \%)$ & $4(20 \%)$ \\
\hline Every 2-3 Years ( 2) & $14(70 \%)$ & $12(60 \%)$ \\
\hline Rarely ( 1 ) & $3(15 \%)$ & - \\
\hline Never ( 0 ) & - & - \\
\hline
\end{tabular}

The table shows that the frequency of updating the textbooks is somewhat higher than for updating the course syllabus. This fluctuation can be due to measurement error caused by the small sample size. Alternatively, it may be an effect of software upgrades or decisions by textbook publishers to issue updated editions.

As can be expected, similar to the changes of the course syllabus, for most instructors (12 out of 20 ) the changes of the textbooks need to be done every 2-3 years. We do not have the results for 


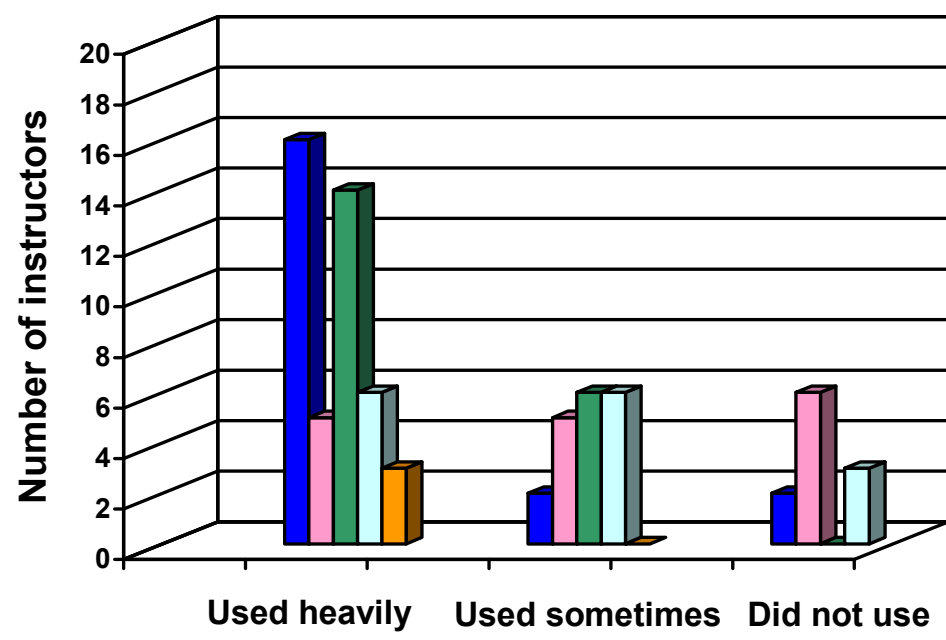

Textbooks

$\square$ Courses given by others

口On-line tutorials

$\square$ Real-life project

口Other

Figure 1: Techniques mainly used for self-education

this question of the survey (question 11, Appendix A) for 20\% (4 out of 20) instructors, as they indicated the question was not applicable since they do not write the textbooks themselves.

The results support hypothesis $\mathrm{H} 2$, that is, the course syllabus of introductory IT courses needs to change every 2-3 years. This conclusion is strengthened by the fact that the course textbooks need to change every $2-3$ years as well.

\section{The methods of self-teaching}

In this section, we evaluate hypothesis $\mathrm{H} 3$, in which we anticipated that instructors primarily teach themselves by using textbooks.

Figure 1 and Figure 2 show the techniques most frequently used for the instructors' selfeducation.

16 instructors heavily use textbooks and 14 use on-line tutorials to update their knowledge. Those are the two techniques most frequently used. Following that, 6 instructors often work on real-life projects and update their knowledge in that way. Courses given by other instructors are the least frequently used. There are 6 out of 20 instructors who never took courses given by other instructors to update their knowledge. Two instructors recommended additional techniques such as "playing with software on my own," and "smaller projects that I use for advising, grades, etc."

Figure 2 shows what the surveyed instructors feel would help them most in the process of their self-education. 


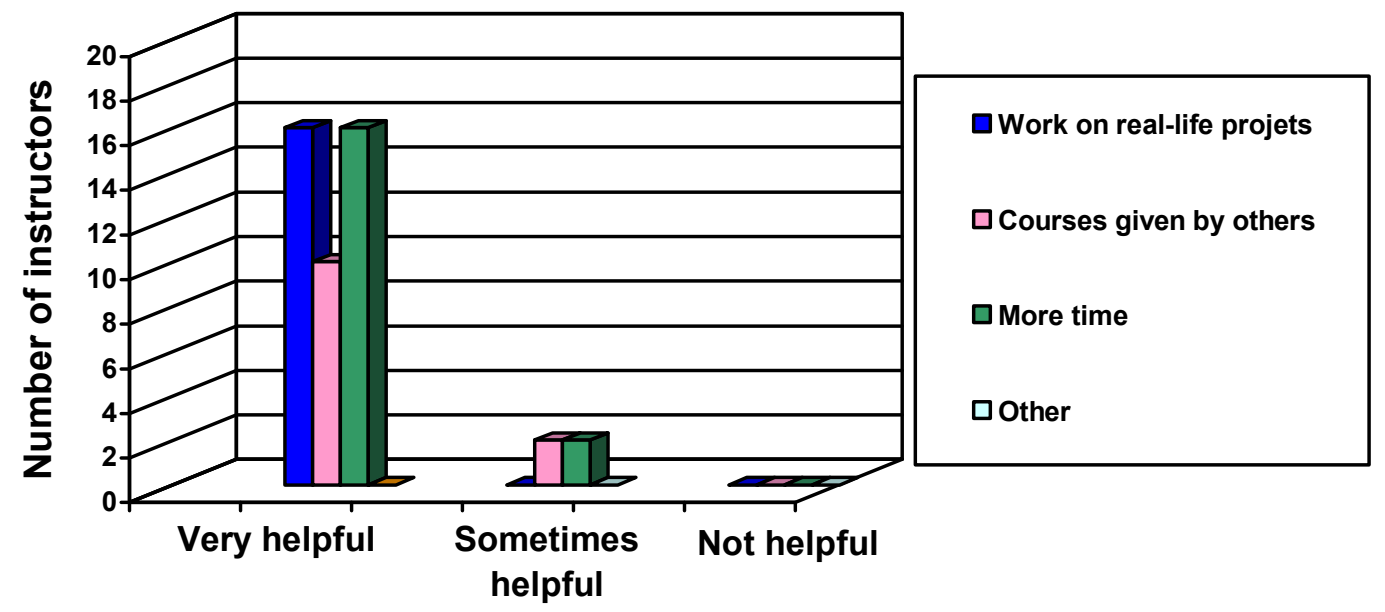

Figure 2: What can help in self-education

Most instructors $(80 \%$, or 16 out of 20$)$ agree that working on real life projects and having more time for their self-education would greatly help them in their self-education. Courses given by others are the next popular technique, and $50 \%$, or 10 out of 20 instructors indicated they would be very helpful.

In regard to the question about experience with people from industry, 45\% (9 out of 20) instructors responded that they had someone from industry teaching a part of their course or lab practice. All of them had a positive experience with this.

Several instructors conveyed that they use published lectures available from foreign schools as a part of their own lectures, which helps students realize they are studying the most up to date technology.

The following is a summary of the main challenges the instructors faced during their selfeducation:

- $55 \%$ (11 out of 20$)$ indicated the lack of time.

- $15 \%$ ( 3 out of 20 ) find it is the lack of practice in real life projects.

- $10 \%$ (2 out of 20$)$ indicated the lack of appropriate literature.

- $10 \%$ (2 out of 20$)$ indicated the lack of motivation.

- $15 \%$ (3 out of 20$)$ do not have any major problems, and find that self-education is assumed in IT.

- A few instructors additionally indicated unusual challenges such as "The lack of vendor sponsored workshops and tutorials," "The lack of money to travel to places where IT is highly developed," or "Figuring out things in complete isolation - no knowledge sharing from colleagues or learning from others."

Supporting hypothesis $\mathrm{H} 4$, the lack of time is most frequently emphasized as a major challenge. Considering the fast pace of IT progress, it is hard for these instructors to stay in the race.

The second major challenge is "the lack of practice working on the real life projects." This could be related to the first challenge, lack of time, as participating instructors indicated that it is hard to find time to work on the projects in addition to fulfilling all other instructors' duties. 


\section{Limitations and Considerations for Future Studies}

Future surveys should be done with a larger number of instructors to allow statistical analysis of data. Future surveys of this type also should finely define some terms in the questionnaire, such as "major change," to insure that these terms are understood in the same way by all participants. Future surveys also could include a broader range of countries and an analysis of responses by country or geographic region. They also might include comparison of syllabi from introductory courses, to allow analysis of technical content from a wide range of participants.

\section{Discussion}

Considering the results of the survey we have conducted, as well as our own experience, we have identified a list of activities that make the process of self-education more efficient and/or effective for IT instructors. These activities include:

1. Taking on-line tutorials.

2. Writing programs independently, using the environment/language/tools covered in the course.

3. Working through the exercises given in textbooks and on-line tutorials.

4. Working on real life projects.

5. Taking courses organized by software companies, community colleges, or continuing education programs

6. Attending IT/CS conferences, seminars, and workshops.

7. Collecting experience from industry people.

8. Using the help of advanced students, either in class or for added activities such as creating and updating Websites (Krunić et al., 2006)..

Different approaches to self-directed learning yield different benefits. For example, many surveyed instructors consider taking courses very helpful. Actually taking courses often involves working in groups, and provides a progress measure of the knowledge acquired. On the other hand, attending conferences, workshops and seminars is indicated as useful by many surveyed instructors because of the opportunity to be in contact with people working in the industry and to collect their experience. Alternatively, some surveyed instructors recommended using industry people to teach a part of their courses. Others emphasized actually doing practical work. Besides writing the programs independently and working through their textbooks' exercises, the surveyed instructors considered working on the real life projects to be extremely useful for staying on top of technologies. Real projects give instructors additional motivation to dedicate time to their selfeducation.

Implementing the ideas suggested here is not always as simple as it might seem on the surface. For example, half of the surveyed instructors feel that taking courses given by other instructors would help them to stay up to date with the technologies. However, most of the instructors conveyed that they do not often actually take those courses, perhaps because of a lack of time or a lack of courses offered. In another example, all Web-based materials are not equal in quality, yet it is important to identify high quality on-line tutorials for instructors' self-education. Instructors should consider the list of selected tutorials provided by Turner (2005). However, as a future work, we recommend collecting a set of good sources of information on the Internet from various IT areas which are most helpful for IT instructors' self-education (e.g., blogs, on-line tutorials, online references, etc.) Also, it may be helpful to conduct a new survey among instructors from a 
particular area to collect and rate the best sources of information according to the instructors themselves.

The IT instructors who participated in our survey were dedicated to continuous self-education. Their dedication to learning provides a strong example for their students, demonstrating that graduation is not the end of education, but rather the beginning of a life of learning.

\section{Conclusion}

While attending university, many contemporary IT instructors studied completely outdated and nowadays almost unrelated computer technologies and tools. In order to teach for many years after their own university graduation, one of the main challenges IT instructors must overcome is the development and implementation of their own continuous self-education program. The frequency of the major changes and breakthroughs in information technology leaves the instructors a very short time in which to update their knowledge and skills. They are often called upon to be the first ones to learn a new technology and be able to teach it.

We have investigated the challenges IT instructors face due to the fast speed of technological advancement. We formed four hypotheses related to those challenges and tested them through a survey among 20 instructors who teach at 10 various colleges and universities. Survey results supported the hypotheses. The technology studied by the IT instructors when they were in school is indeed not the one they must now teach, which requires the instructors to work hard to update their knowledge. The course syllabus of the introductory IT courses changes every two or three years due to the changes in technology, and the instructors find it challenging to update the syllabus as well as their knowledge that frequently.

The instructors still primarily self-teach new technologies by using textbooks. On the other hand, most of them agree that learning through practical work or taking courses given by others would be very helpful, but usually the lack of time stops them from doing so.

We may conclude that IT instructors need more time to dedicate to their self-education. It may be necessary to include this time as a part of their everyday duties, i.e., as a part of their "job description." Further discussion on this topic may be a subject of another survey and we leave it for future research.

We have to emphasize the limitation of the method of our research, including the small sample of the instructors who participated in our survey. However, although the surveyed instructors teach in various universities and countries, we found that most of them indicated the same challenges and offered similar recommendations.

While the focus of the research in this paper is on teaching introductory computer science courses, this work can also be expanded to tackle more specific challenges IT instructors of the specific IT areas, such as web development and design, databases, programming languages, and hardware components. The goal of such research would be to collect ideas and recommendations for the instructors of specific IT areas to help improve their process of self-education, and help overcome other challenges they may face. 


\section{References}

Aasheim, C., Lee, C. K., \& Reichgelt, H. (2006). An implementation of the IT fundamentals knowledge area in an introductory IT course. Journal of Information Technology Education, 5, 373-388. Retrieved from http://www.jite.org/documents/Vol5/v5p373-388Aasheim129.pdf

Cohen, E. B. (Ed.). (2002). Challenges of information technology education in the 21 st century. IGI Publishing.

Cox, M. (2007). The changing nature of researching IT in education. AERA 2007 IFIP Symposium.

Crawford, R. (2000). Information technology in secondary schools and its impact on training information technology teachers. Journal of Information Technology for Teacher Education, 9 (2), 183-197.

Cromley, J. G. (2000). Learning with computers: The theory behind the practice. Focus on Basic, 4(Issue C)

Cuban, L. (2003). Oversold and underused: Computers in the classroom. Harvard University Press

Dadashzadeh, M., Saber, A., \& Saber, S. (2002). Information technology education in the new millennium. IRM Press.

Helps, R., \& Renshaw, S. (2004). Design of a flexible case-study instructional module for operating systems for information technology. Proceedings of the 5 th conference on Information technology education 2004, Salt Lake City, UT, USA, p.56-59.

Hiemstra, R. (1994). Self-directed learning. In T. Husen \& T. N. Postlethwaite (Eds.), The international encyclopedia of education (2nd ed.), Oxford: Pergamon Press.

Hoffman, M., \& Blake, J. (2003). Computer literacy: Today and tomorrow. Journal of Computing Sciences in Colleges, 18(5), 221 - 233.

Johnson, D. W., Bartholomew, K. W., \& Miller, D. (2006). Improving computer literacy of business management majors: A case study. Journal of Information Technology Education 5, 77-94. Retrieved from http://www.jite.org/documents/Vol5/v5p077-094Johnson100.pdf

Krunić, T., Ružić-Dimitrijević, L., Petrović, B., \& Farkaš, R. (2006). Web design curriculum and syllabus based on Web design practice and students' prior knowledge. Journal of Information Technology

Education, 5, 317-335. Retrieved from http://www.jite.org/documents/Vol5/v5p317-335Krunic153.pdf

Luger, E. (2006). A literature review of exemplary practice in the training of IT tutors. UK: National Institute of Adult and Continuing Education.

McGill, T. (Ed.). (2003). Current issues in IT education. USA: IRM Press.

Resta, P. (Ed.). (2002). UNESCO Report: Information and communication technologies in teacher education - A planning guide. UNESCO.

Turner, L., (2005, June). 20 technology skills every educator should have. THE Journal. Retrieved November 18, 2006 from http://thejournal.com/articles/17325 _

Webb, M. (2002). Pedagogical reasoning: Issues and solutions for the teaching and learning of ICT in secondary schools. Education and Information Technologies, 7(3), 237-255. 


\section{Appendix A}

\section{Survey: Teaching Introductory Computer Science Courses and Instructor's Self-Education}

1. What introductory computer science courses have you taught over the last 10 years and at what department(s)?

2. What software technologies (programming languages, operating systems, graphic tools, etc) have you taught at each course?

3. What software technologies (programming languages, operating systems, etc) have you studied at your undergraduate studies?

4. What year did you acquire your undergraduate degree?

5. How frequently have you made major changes in the syllabus for each course, due to the advance of the software technology over the last 10 years?

6. How frequently have you had to make changes in the syllabus of the introductory CS courses you taught in order to meet the requirements of other courses that the students would take in the following semesters?

7. Have you ever had someone from the industry teach a part of your course or the labs for the course?

8. What techniques have you mainly used in order to educate yourself for the new technologies that you taught in the introductory CS courses?

Please rate the following:

1 - Used heavily 2 - Used sometimes 3 -Did not use

Textbooks

Courses given by other instructors

On-line tutorials

Working on real-life projects from the industry

Please list any other:

9. What do you feel would have helped the process of your self education?

Please rate the following:

1 - Highly helpful 2 -Somewhat helpful $\quad 3$ - Not helpful

Working on real-life projects from the industry

Courses/lectures given by other instructors

Having more time to learn on my own from the books or on-line tutorials

Please list any other:

10. What were the main challenges you faced during your self-education?

11. If you wrote textbooks for introductory computer science courses, in what time on average do you feel they needed to be updated due to the advances in the software industry?

12. What do you recommend to the instructors of the introductory CS courses for their most efficient self education? 


\section{Appendix B}

\section{List of Universities and Colleges Where the Surveyed Instructors Teach (with numbers of participants between the brackets)}

1. Advanced Electrical Engineering School, Belgrade, Serbia (3)

2. Advanced Technical School, Novi Sad, Serbia (2)

3. Faculty of Electrical Engineering, University of Belgrade, Serbia (2)

4. Faculty of Mathematics and Natural Sciences, University of Belgrade, Serbia (2)

5. Faculty of Mathematics and Natural Sciences, University of Novi Sad, Serbia (3)

6. Kennesaw State University, USA (1)

7. Salford Business School, University of Salford, UK (1)

8. University of British Columbia, Canada (3)

9. University of Agriculture, Nigeria (1)

10. University of Manitoba, Canada (2)

\section{Biographies}

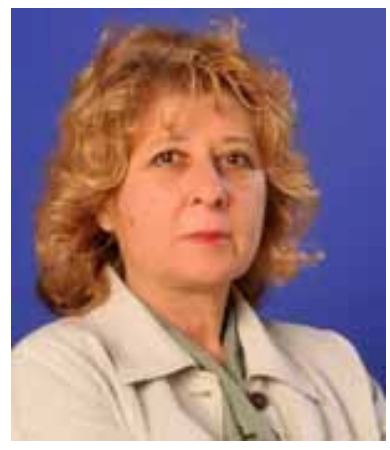

Ljiljana Ružić-Dimitrijević is a professor at the Advanced Technical School, Novi Sad, Serbia. She teaches courses in computers, computer graphics, and development of the Internet. She got her MSc degree in mathematics at the Center of Multidisciplinary Studies, Belgrade in 1991. Her field of expertise is computer graphics and web design. She is head of the graphic department at the Advanced Technical School.

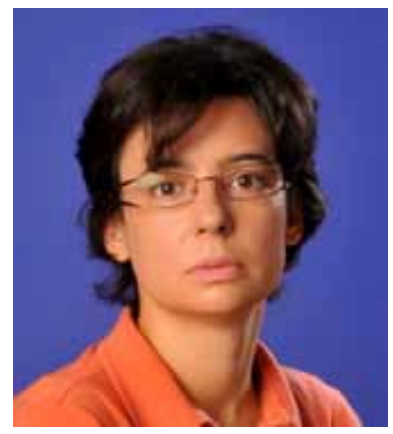

Maja Dimitrijević is a software developer and independent consultant at Sat Consulting, Vancouver, Canada. She holds an MSc degree in Computer Science from the University of British Columbia, Vancouver, Canada. She has 5 years of experience in web and desktop application development. Her expertise and her work at the Master studies include data mining and artificial intelligence algorithms. 